\title{
APPLICATION OF FUNDAMENTAL ANALYSIS \\ IN INVESTMENT DECISION MAKING: EXAMPLE OF A DOMESTIC BUSINESS ENTITY
}

\author{
Pavle Dakić ${ }^{1}$ \\ Luka Filipović ${ }^{2}$ (D) \\ Marko Starčevićc ${ }^{3}$ (it)
}

DOI: https://doi.org/10.31410/ITEMA.S.P.2019.149

\begin{abstract}
The subject of this research is to analyze the methods of fundamental investment analysis on the example of stocks of a domestic company listed on the Belgrade Stock Exchange. The aim of the research is to obtain concrete information on the possibilities of improving the effective management of the portfolio of shares of this company with a special focus on the optimal selection of techniques and methods of fundamental analysis that deals with the study of economic, political and social indicators of the national economy in order to predict trends in the financial market into the future. The methodology used in this paper includes exploratory technique methods as well as analysis and synthesis methods. The results of the research will be useful to the academic community for further research in this area as well as to future investors.
\end{abstract}

Keywords: Fundamental Analysis, Investments, Stocks, Belgrade Stock Exchange

\section{INTRODUCTION}

T tock exchanges and trading on them can be viewed from different perspectives depending on

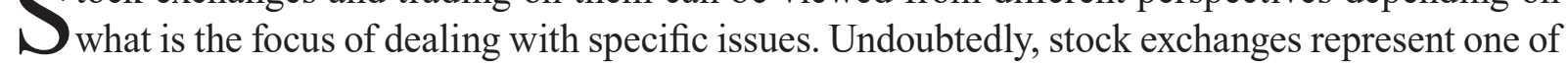
the most significant, if not the most significant market institution, at least it is in the countries with developed capital markets, which is not the case with the capital market of the Republic of Serbia, but we certainly hope that this circumstances will change in the nearer or, in the worst case, in the further future. According to Andjelic and associates (2017) the overall socio-economic climate depends to a large extent on the situation and opportunities on them, the volume of trading, the number of participants, the safety of business. The link between the achieved level of socio-economic development and stock market conditions and opportunities has been confirmed in a large number of studies, but constantly changing market environment conditions place increasing demands on policy makers to analyze, view and test contemporary aspects of stock trading in the light of an effective response to changing environmental conditions (p. 2). An investment strategy that involves making investment decisions when investing in a particular portfolio of stocks must be based on fundamental or technical analysis, or both of them, depending on the spatial diversification of the portfolio and the investor's attitude and attitude to risk, and thus the yield.

In the moment of breakdown of price movements of financial instruments, it is very important to identify the factors that influence the price movement of those instruments. Fundamental analysis of investments in financial instruments deals with the study of economic, political and social indicators of the national economy with the aim of predicting price movements in the financial market

\footnotetext{
Singidunum University, Danijelova 32, 11000 Belgrade, Serbia

EuroAudit 1lc, Bvld. despota Stefana 12, 11000 Belgrade, Serbia

Union-Nikola Tesla University, Knez Mihailova 33, 11000 Beograd, Serbia
} 
in the future. In the broadest sense, fundamental analysis is concerned with analyzing all the data that may have an impact on the price movement of financial instruments. The fundamental data that this type of analysis deals with is economic factors, then, trends specific to a particular industry, capital market conditions, and last but not least, specific company-specific data. In the framework of fundamental analysis, quantitative factors are studied, which include specific indicators of company performance and market functioning, as well as qualitative and / or intangible indicators, such as quality of technology or efficiency of management. According to Steinberg (2000), by understanding the fundamentals of fundamental analysis, as well as a more thorough observation of the fundamental economy, understanding of the financial market can be greatly improved, thereby improving the efficient management of securities and investing in financial instruments (p. 56).

In this paper, a fundamental analysis of the investment in the stocks of domestic company (furthermore the Company) was applied. The Company was privatized in early 2008. In the same year, the foreign investor, a strategic partner of the Company bought a controlling stake in the state for a total value of $€ 400$ million and acquired ownership of $51 \%$ of the company.

The continuation of this paper follows the application of fundamental analysis to invest in equity securities of this company.

In accordance with the foregoing, this paper starts from the following hypotheses:

H1: The market value of the stock of the analyzed company is not overstated relative to the generated revenues.

H2: Using a fundamental analysis, one can estimate the undervaluation of a financial instrument in the capital market.

\section{FUNDAMENTAL ANALYSIS}

The market price of stocks is one of the key indicators of the success of a business entity, and for investors it is a basic indicator of which the justification of investment in a particular financial instrument can be measured. A share is actually an equity security that has a certain nominal value, is part of the share capital of a company and is issued by a joint stock company. In order for an investor to make the most favorable decision on investing in a particular financial instrument, it is crucial to carry out both technical and fundamental analysis - which is the subject of research in this paper. In the broadest sense, the goal of fundamental analysis is to identify the real value of the shares of a particular company and compare it with the market price. According to Jagongo and Mutswenje (2014), fundamental analysis of a company is one of the important factors that affect individual investment decision (p. 99). Hou and associates considered in their work (2011) that fundamental factors as the main factors that affect the movement of the stock return (p. 2573). It can be used to predict the future earnings or return. Anywise, there are quite a few papers which support the predicting power of fundamental analysis. In the prior studies, Ou and Penman (1989) suggested that abnormal return can be predicted by using fundamental analysis. (p. 296) Abarbanell and Bushee (1998) used the accounting ratio that consists of conceptual and theoretical background (p. 27). They focus on individual signal to evaluate the strength of predictive power of each signal instead of combine the predictors into a summary measure. Therefore, the contextual that influence their credibility can be investigated.

According to Suresh Kumar and Elango (2011) fundamental analysis supposed, that the current and the future stock price depended on the characteristic value of the stock and the expected return. As and when new information about the company was disengaged, the analysis got 
updated as the expected return changed. Accordingly, the changes in the stock prices were predicted even before the change de facto happened. The economy and industry analysis in the background also helped to forecast the growth opportunities for stocks (p. 45). Furthermore, Sureshkumar and Elango (2011) concluded that this type of analysis assumes that a stock's current (and future) price depends on its intrinsic value and anticipated return on investment. As new information is released relative to the company's status, the expected return on the company's stocks are going to change, which disembogues their value. The advantages of fundamental analysis are its ability to predict changes before they show up on the charts (p. 45).

In order to estimate the fair value of stocks, many authors used valuation models by Fundamental Analysts in stock markets, these analysts use information of current, future and in some cases past earnings of the company to evaluate the fair value (Bernard, 1994; Fischer, Jordan, 1995; Penman, 1991; Bauman, 1996; Rielly, Brown, 2002; Jones, 2007 and Bodie, et al, 2009), and then compared with the market value to determine whether it was possible to invest in or to be excluded.

According to Dzelatovic and Milosevic, fundamental analysis uses earnings and dividend prospects from the company, expectations of future interest rates, and estimates of the company's risk to determine the true stock price. Fundamental analysts usually start with a study of past earnings and an examination of the company's balance sheet. Later, the analysis is supplemented with detailed economic analyzes, usually including an assessment of the quality of the company's management, the status of the firm in its business, and the prospects of the industry as a whole (p. 50). After all, fundamental analysis is an attempt to determine the instant discounted value of all payments a shareholder will receive from each share. If, by fundamental analysis, the determined value exceeds the stock price, the fundamental analyst would recommend the purchase of a block of shares. The goal of fundamental analysis is to identify the performance of a company that is not yet recognized in the market. However, the efficient market hypothesis predicts that most fundamental analyzes are doomed, and this is why fundamental analysis is difficult to evaluate.

\section{INVESTMENT DECISION-MAKING ON THE CASE OF DOMESRIC COMPANY BY APPLYING FUNDAMENTAL ANALYSIS}

When making investment decisions, investors consuetude a variety of analysis techniques. They analyze the financial statements in the way of reviewing the organizations financial position and collect relevant information. Investors are very important stakeholders through which large companies come to the required capital. They use information from the financial statements for the purpose assessing the quality of company results and as basis for predicting future value society. Also, in addition to financial statements, they use other sources of information as well, information such as investment service, publications which were published by large brokerages, expert magazines, etc. According to Richard et al (2009) Investors can do a fundamental analysis combine with technical, quantitative analysis and analysis of financial behavior, where a rational analysis is thus obtained (p. 723).

At the beginning of 2008, the analyzed company was privatized for $€ 800$ million. Strategic foreign partner bought a controlling stake in the state for a total value of $€ 400$ million and acquired ownership of $51 \%$ of the company. Free stocks were distributed to citizens, each with 5 stocks. Company stocks appear on the Belgrade Stock Exchange in August 2010 with a price of 505 dinars per unit. In accordance with the provisions of the Public Takeover Bid Law, in the 
spring of 2011, foreign partner purchased an additional 5\% of the shares and acquired $56 \%$ of the total ownership of the Company. Foreign partner bought Bid for 505 dinars or 4.8 euros for the offer to take over the Company's share.

In years 2010-2011 the Company achieved excellent business result. The price stocks increased from 505 (30.08.2010) to over 800 dinars in 2011. In the spring of 2013, there was a sharp jump in the stock price. Instead of the announced dividend payment of $15 \%$, the Company paid $25 \%$ of dividend income in April 2013 when stock price recorded a historical high of RSD 1,020. The fall of 2014 marked the beginning of the oil crisis when the price of crude oil dropped sharply by $70 \%$, from over $\$ 100$ per barrel to just $\$ 30$ in early 2016, indicating a disruption in the global oil market (in 2009- In the 10th year they started exporting alternative oil from shale). During years 2012-13. excise taxes and other taxes (sales tax, reserve tax) increased, and as excise taxes are fixed and burden over $40 \%$ of Company's fuel sales price, the recorded decrease in crude oil prices on the world market did not drastically affect the decrease in gasoline prices.

In the period 2014-15. Company recorded a decrease in revenues and a fall in profitability, as well as an increase in debt. Other companies in this industry have a high level of indebtedness due to the high costs of finding new sites, innovating equipment, research and development and large investments. In addition, negative foreign exchange gains and losses resulting from the strengthening of the USD against the RSD contributed to the poor business results. In January 2016, the price of crude oil was at a multi-year low of $\$ 30$ per barrel, when Company's shares fell below 500 dinars. In 2016, sanctions imposed by Russia on the European Union also affected foreign partner, which is a state-owned company. In 2016, the Company made only $€ 100$ million in profit, while in 2013-14. Profit amounted to EUR 400 million. In 2016, the Company had a $45 \%$ market share in the retail market and a share of over $60 \%$ in the wholesale market. Company's dividend yield in 2016 was about 3\%.

At the end of 2016, OPEC decided that from 01.01.2017. will reduce the amount of crude oil produced to influence the rise in the price of crude oil. Russia and Saudi Arabia also joined the decision, bringing the price of crude oil up to $\$ 55$ in early 2017. During 2017, the price of Company's stocks ranged from 700 to 750 dinars. At the beginning of 2018, Company had a market capitalization of EUR 1 billion. The price of crude oil in early 2018 rose to $\$ 70$ per barrel as a result of the decline in crude oil produced by the OPEC agreement. The growth of Company's revenues in 2017 was generated by the increased price of oil, but also by the strengthening of RSD against USD and EUR (revenues based on exchange rate differences). The price of Company's stock at the beginning of 2018 was around 720 dinars.

Table 1 shows the Basic Characteristics of a Company's Business, and Tables 2 and 3 represent summarized financial Statements of the Company.

Table 4 presents the Basic Financial and Price Indicators.

In 2016, the value of assets increased by $1.20 \%$ compared to 2015 , fixed assets by $10.92 \%$ and current assets decreased by $21.14 \%$. In 2016 , the value of liabilities increased by $1.20 \%$ compared to 2015 , capital increased by $3.77 \%$, long-term liabilities increased by $6.98 \%$, while short-term liabilities decreased by $12.87 \%$. During 2017, the value of assets continued to grow, and compared to 2016 it increased by $1.74 \%$, fixed assets increased by $4.54 \%$, current assets decreased by $7.32 \%$. Liabilities increased by $1.74 \%$ in 2017 , equity increased by $8.23 \%$, long-term liabilities 
decreased by $5.98 \%$, while short-term liabilities decreased by $4.47 \%$. During 2018 , the value of assets increased by $4.43 \%$, fixed assets decreased by $1.35 \%$ while current assets increased by $25.51 \%$. Liabilities increased by $4.43 \%$ in 2017 compared to 2017 , equity increased by $15.72 \%$, long-term liabilities decreased by $2.62 \%$, while short-term liabilities decreased by $16.40 \%$.

Table 1. Basic business characteristics of the company

\begin{tabular}{|l|l|l|}
\hline \multicolumn{1}{|c|}{ 2015. } & \multicolumn{1}{|c|}{ 2016. } & \multicolumn{1}{c|}{$\mathbf{2 0 1 7 .}$} \\
\hline $\begin{array}{l}\text { Major disruptions in the global oil } \\
\text { market }\end{array}$ & $\begin{array}{l}\text { Major disruptions in the global oil } \\
\text { market }\end{array}$ & $\begin{array}{l}\text { Price recovery in the world oil mar- } \\
\text { ket }\end{array}$ \\
\hline Decline in revenue and profitability & Decline in revenue and profitability & Revenue and profitability growth \\
\hline Debt growth & Debt growth & Pos. effects of exch. differences \\
\hline Significant decline in net profit & Continued trend of decl. net profit & Net profit growth \\
\hline $\begin{array}{l}\text { High negative exch. rate diffs. (ex- } \\
\text { change rate losses due to falling oil } \\
\text { prices) }\end{array}$ & $\begin{array}{l}\text { Business rationalization through ef- } \\
\text { ficiency gains }\end{array}$ & $\begin{array}{l}\text { Business rationalization through ef- } \\
\text { ficiency gains }\end{array}$ \\
\hline
\end{tabular}

Table 2. Summarized Company Balance Sheet (in RSD billion) ${ }^{4}$

\begin{tabular}{|l|r|r|r|r|}
\cline { 2 - 4 } \multicolumn{1}{c|}{} & \multicolumn{1}{c|}{$\mathbf{2 0 1 5 .}$} & $\mathbf{2 0 1 6 .}$ & \multicolumn{1}{c|}{$\mathbf{2 0 1 7 .}$} & $\mathbf{2 0 1 8 . f ^ { * }}$ \\
\hline Assets & $\mathbf{3 6 1 . 6 6 7}$ & $\mathbf{3 6 6 . 0 1 6}$ & $\mathbf{3 7 2 . 3 8 3}$ & $\mathbf{3 8 8 . 9 0 0}$ \\
\hline Fixed assets & $\mathbf{2 5 2 . 0 1 4}$ & $\mathbf{2 7 9 . 5 3 9}$ & $\mathbf{2 9 2 . 2 3 4}$ & $\mathbf{2 8 8 . 3 0 0}$ \\
\hline Property, plant and equipment & 232.390 & 247.213 & 259.908 & 231.500 \\
\hline Goodwill and other intangible assets & 7.494 & 7.155 & 7.155 & 3.100 \\
\hline Sales receivables and other long-term receivables & 73 & 14.657 & 24.849 & 3 \\
\hline Long term investments & 241 & 321 & 321 & 296 \\
\hline Working assets & $\mathbf{1 0 9 . 6 5 3}$ & $\mathbf{8 6 . 4 7 7}$ & $\mathbf{8 0 . 1 5 0}$ & $\mathbf{1 0 0 . 6 0 0}$ \\
\hline Supplies & 39.131 & 24.178 & 25.200 & 27.500 \\
\hline Receivables & 51.691 & 34.979 & 28.800 & 31.500 \\
\hline Short-term financial placements & 6 & 201 & 2.072 & 16.400 \\
\hline Cash and cash equivalent & 8.326 & 19.271 & 16.200 & 23.700 \\
\hline Liabilities & $\mathbf{3 6 1 . 6 6 7}$ & $\mathbf{3 6 6 . 0 1 6}$ & $\mathbf{3 7 2 . 3 8 3}$ & $\mathbf{3 8 8 . 9 0 0}$ \\
\hline Capital & $\mathbf{1 8 3 . 7 7 4}$ & $\mathbf{1 9 0 . 6 9 8}$ & $\mathbf{2 0 6 . 3 8 4}$ & $\mathbf{2 3 8 . 8 3 0}$ \\
\hline Share capital & 81.530 & 81.530 & 87.149 & 81.530 \\
\hline Undistributed profit & 102.696 & 109.698 & 119.235 & 157.300 \\
\hline Long-term liabilities & $\mathbf{1 0 2 . 6 0 1}$ & $\mathbf{1 0 9 . 7 6 5}$ & $\mathbf{1 0 3 . 2 0 0}$ & $\mathbf{1 0 0 . 5 0 0}$ \\
\hline Long-term provisions & 9.013 & 9.451 & 11.000 & 9.100 \\
\hline Long-term financial liabilities & 93.588 & 100.314 & 92.200 & 91.400 \\
\hline Short-term liabilities & $\mathbf{7 5 . 4 4 6}$ & $\mathbf{6 5 . 7 3 9}$ & $\mathbf{6 2 . 8 0 0}$ & $\mathbf{5 2 . 5 0 0}$ \\
\hline Short-term financial liabilities & 14.832 & 17.136 & 14.000 & 10.400 \\
\hline Business duties & 43.752 & 29.364 & 28.800 & 25.300 \\
\hline Other current liabilities & 5.322 & 6.538 & 20.000 & 4.100 \\
\hline
\end{tabular}

Source: Official database of the agency for business registers of the Republic of Serbia (APR)

In 2016, sales revenue decreased by $18.51 \%$ compared to 2015 , while operating expenses decreased by $14.51 \%$. EBITDA decreased by $26.66 \%$ in 2016 , EBIT decreased by $38.05 \%$, EBT decreased by $43.74 \%$, net profit decreased by $47.52 \%$. In 2017 , we continue to see a downward trend in sales revenue by $14.56 \%$, while operating expenses decreased by only $8.70 \%$. In the same year, EBITDA decreased by $25.24 \%$ compared to 2016, EBIT decreased by $43.77 \%$, EBT decreased by $21.49 \%$, while net profit decreased by $12.95 \%$ compared to 2016 . In 2018 , Company generated sales revenue that was $30.55 \%$ higher than in 2017, while operating expenses increased $23.81 \%$ in the observed year. In 2018, EBITDA grew by $48.14 \%$, EBIT growth by $93.58 \%$, EBT growth by $137.30 \%$ and net profit growth by $120.19 \%$.

$4 \quad 2018 f^{*}$ - estimated data based on nine-month company reports. 
Table 3. Summarized Income statement of the analyzed company (in RSD billion) ${ }^{5}$

\begin{tabular}{|c|c|c|c|c|}
\hline & 2015. & 2016. & 2017. & 2018. f* \\
\hline Revenues from sales & 258.527 & 210.679 & 180.000 & 235.000 \\
\hline Business expenses & 207.314 & 177.975 & 162.500 & 201.200 \\
\hline Cost of oil, gas and petroleum products & 147.664 & 122.164 & 110.000 & 119.500 \\
\hline Production and processing costs & 18.116 & 18.905 & 17.200 & 37.2502 \\
\hline Sales costs, general and administrative expenses & 20.263 & 16.539 & 15.400 & 17.100 \\
\hline Depreciation expense & 12.757 & 14.282 & 14.200 & 17.700 \\
\hline EBITDA & 63.400 & 46.500 & 34.765 & 51.500 \\
\hline EBIT & 50.126 & 31.051 & 17.460 & 33.800 \\
\hline Financial income & 397 & 430 & 500 & 1.200 \\
\hline Financial expenses & 3.420 & 4.364 & 900 & 3.100 \\
\hline Foreign exchange differences & 13.234 & 8.061 & 1.100 & 7.200 \\
\hline EBT & 33.870 & 19.056 & 14.960 & 35.500 \\
\hline Income tax & 6.031 & 4.448 & 2.244 & 7.500 \\
\hline Net gain & 27.838 & 14.608 & 12.716 & 28.000 \\
\hline
\end{tabular}

Source: Official database of the agency for business registers of the republic of Serbia (APR)

Table 4. Basic financial and price indicators ${ }^{6}$

\begin{tabular}{|c|c|c|c|c|}
\hline & 2015. & 2016. & 2017. & 2018.f* \\
\hline \multicolumn{5}{|l|}{ Financial indicators } \\
\hline \multicolumn{5}{|l|}{ Liquidity } \\
\hline General Liquidity Ratio & 1,45 & 1,32 & 1,28 & 1,92 \\
\hline Reduced liquidity ratios & 0,93 & 0,95 & 0,88 & 1,39 \\
\hline \multicolumn{5}{|l|}{\begin{tabular}{|l|} 
Solvency \\
\end{tabular}} \\
\hline Fin. liabilities / equity & 1,33 & 1,44 & 1,34 & 1,36 \\
\hline Fin. liabilities / total equity & 0,59 & 0,62 & 0,57 & 0,46 \\
\hline Fin. liabilities / total assets & 0,30 & 0,32 & 0,31 & 0,29 \\
\hline \multicolumn{5}{|l|}{ Profitability } \\
\hline EBITDA margin & $24,52 \%$ & $22,07 \%$ & $19,31 \%$ & $21,91 \%$ \\
\hline Net profit margin & $10,77 \%$ & $6,93 \%$ & $7,06 \%$ & $11,91 \%$ \\
\hline $\mathrm{ROA}$ & $7,70 \%$ & $3,99 \%$ & $3,41 \%$ & $7,20 \%$ \\
\hline ROE & $15,15 \%$ & $7,66 \%$ & $6,16 \%$ & $11,72 \%$ \\
\hline \multicolumn{5}{|l|}{ Price indicators } \\
\hline Earnings per share in RSD (EPS) & 170,72 & 89,59 & 77,98 & 171,72 \\
\hline Stock price & 534 & 534 & 740 & 714 \\
\hline $\mathrm{P} / \mathrm{E}$ ratio & 3,13 & 5,96 & 9,49 & 4,16 \\
\hline $\mathrm{P} / \mathrm{S}$ ratio & 0,34 & 0,41 & 0,67 & 0,49 \\
\hline $\mathrm{P} / \mathrm{B}$ ratio & 0,47 & 0,46 & 0,56 & 0,49 \\
\hline
\end{tabular}

Source: Author's calculations

The EBITDA operating result before depreciation shows the efficiency of the company when interest, depreciation and amortization are neglected. Therefore, a higher EBITDA margin indicates a higher degree of business efficiency. In the observed period, EBITDA margin is quite favorable. The net profit margin shows how much profit a company generates in terms of revenue and represents a ratio of revenue to cost. It is desirable to be as large as possible, but the amount also depends on the industry: low net profit margins are experienced by heavy industry companies, construction companies as a capital-intensive branch with large costs of the underlying asset, which hardly earn a net profit margin of more than $10 \%$ in 2015. and nearly $12 \%$ in first nine months of 2018.

\footnotetext{
$52018 f^{*}$ - estimated data based on nine-month company reports.

$62018 f^{*}$ - Indicators calculated using estimated data based on nine-month company reports.
} 


\section{CONCLUSION}

During 2017, the analyzed company achieved a $11.91 \%$ net profit margin. In other words, the company made a profit of RSD 11.91 per 100 dinars of revenue. The return on assets, ROA in 2017 was a solid $7.20 \%$ and shows how much profit Company has made in relation to assets. In the same year, the company had a return on equity, a ROE of $11.72 \%$, which is considered a good result. Stock gain of 171.72 din. represents the maximum dividend payout amount and actually shows how much 1 stock earned during 2018.

By analyzing the basic financial and price indicators, as well as considering the basic business indicators, RSD exchange rate and crude oil price in 2018, we conclude that the stock is undervalued, and rational investors would use the elements of fundamental analysis to buy Company shares with expectations about rising stock price in the future. The low level of $\mathrm{P} / \mathrm{E}$ ratio with high, rising EPS indicates that Company's stock is undervalued. The $\mathrm{P} / \mathrm{B}$ ratio is lower than 1 and indicates that Company's stock is undervalued and that its market value represents only $49 \%$ of its book value. This all indicates that the first hypothesis, which states that the market value of the shares of the analyzed company is not overestimated relative to the earned income, on the contrary, the stock of this company is undervalued. The P/S ratio shows how much investors are willing to pay per dinar of sales. A low ratio may indicate the stock is undervalued, while a ratio that is significantly above the average may suggest overvaluation. The $\mathrm{P} / \mathrm{S}$ ratio shows that the market value of the stock is not overstated relative to the company's revenue. Since it is desirable that this ratio be below 1, the company is profitable because it generates excellent profit from high income. With this sales revenue, the company can generate net profit margin, ROE and ROA growth.

Since we have applied fundamental analysis techniques, as well as analyzed basic financial and price indicators, considering the basic business indicators, movements of the RSD exchange rate and crude oil price in 2018, we were able to determine that the price of this company's shares is undervalued, it follows that the second hypothesis Using a fundamental analysis, one can estimate the undervaluation of a financial instrument in the capital market can be validated and accepted as valid.

\section{REFERENCES}

Abarbanell, S., Bushee, J., (1998). Abnormal returns to Fundamental analysis strategy. The analysis. Research Starters Business, 1-5. Accounting Review, 73(1), 19-45.

Anđelić, et. al. (2016). New development trends of commodity exchanges through the prism of modern standards. Poslovna ekonomija, 10(2), 1-27.

Bauman, M., (1996). A review of Fundamental Analysis Research in Accounting. Journal of Accounting Literature. 15, 1 - 33.

Bernard, L., (1994). Accounting-based valuation methods, determinants of market-to-book ratios, and implications for financial statements analysis. Working paper. (University of Michigan. Business School. Faculty Research). No. 9401.

Bettman, J., Sault, S., Schultz, E., (2009). Fundamental and Technical analysis: Substitutes or complements. Accounting and finance. 49 1, $21-36$.

Bodie, Z., Kan, A., Marcus, J., (2009). Investments. 8th Ed. McGraw-Hill Irwin.

Dzelatovic, M., Milosevic, M., (2017). Fundamentalna i tehnička analiza u funkciji efikasnog upravljanja portfoliom HoV, Business Economics year 11 No 1, 47-68. 
Fisher, E., Jordan, J., (1995). Security Analysis and Portfolio Management. 6th Ed. Prentice-Hall, New York, N.Y.

Gould, M. (2016). Fundamental vs. technical financial analysis. Research Starters Business, 1-5.

Hou, W., Kho, K., Karolyi, G.A. (2011). What factors drive global stock returns? Review of Financial Studies, 24(8), 2527-2574.

Jagongo, A., Mutswenje, S. (2014). A survey of the factors influencing investment decision: The case of individual Investors at NSE, International Journal of Humanities and Social Science, (4), 92-102.

Jones, P., (2007). Investment. 10th Ed. John Wiley \& Sons, Inc.

Ou, J., Penman, H., (1989). Financial statement analysis and the prediction of stock returns, Journal of Accounting and Economics 11, North-Holland 295-329.

Penman, H., 1991. An evaluation of accounting rate-of-return. Journal of Accounting, Auditing \& Finance. 6, 2, $233-255$.

Reilly, F., Brown, K., 2002. Investment Analysis and Portfolio management. 7th Ed. South-Western.

Richard, P. et al, Measuring Organizational Performance: Towards Methodological Best Practice, Journal of Management, vol. 35, No. 3, 2009.

Steinberg, M. (2000), Guide to Investing, Third Edition, New York Institute of Finance, Prentice Hall Press.

Sureshkumar, K., Elango, M. (2011). An efficient approach to forecast Indian stock market price and their performance analysis. Int. Journal of Computer Application, 34 (5), 44-49. 